\title{
A molecular key to the common species of Trichogramma of the Mediterranean region
}

\author{
Fahriye Sumer $\cdot$ Aydın S. Tuncbilek • \\ Sevcan Oztemiz • Bernard Pintureau • \\ Paul Rugman-Jones $\cdot$ Richard Stouthamer
}

Received: 11 December 2008/Accepted: 30 March 2009/Published online: 18 April 2009

(C) The Author(s) 2009. This article is published with open access at Springerlink.com

\begin{abstract}
A molecular key for the identification of common Trichogramma (Hymenoptera: Trichogrammatidae) species found in agricultural settings around the Mediterranean is developed based on the sequence of the internal transcribed spacer 2 of the ribosomal cistron. Using the size of the ITS2 PCR product and restriction fragment length polymorphisms of the amplicon, ten Trichogramma species (T. bourarachae Pintureau and Babault, T. brassicae Bezdenko, T. cacoeciae Marchal/T. embryophagum
\end{abstract}

Handling editor: Dirk Babendreier.

F. Sumer · A. S. Tuncbilek

Department of Biology, Faculty of Science and Art,

Erciyes University, Kayseri, Turkey

F. Sumer

e-mail: fahriyesumer@gmail.com

S. Oztemiz

Biological Control Department, Plant Protection Research

Institute, Adana, Turkey

B. Pintureau

UMR INRA/INSA de Lyon, Biologie Fonctionnelle, Insectes et Interactions, Villeurbanne, France

e-mail: Bernard.Pintureau@lyon.inra.fr

P. Rugman-Jones · R. Stouthamer $(\square)$

Department of Entomology, University of California,

Riverside, CA 92521, USA

e-mail: richard.stouthamer@ucr.edu

P. Rugman-Jones

e-mail: paulrj@ucr.edu
Hartig, T. cordubensis Vargas and Cabello, T. dendrolimi Matsumura, T. euproctidis Girault, T. evanescens Westwood, T. nerudai Pintureau and Gerding, T. oleae Voegelé and Pointel, and T. pintoi Voegelé) can be distinguished.

Keywords Trichogramma $\cdot$ rDNA ·

Taxonomy $\cdot$ Internally transcribed spacer 2

\section{Introduction}

Trichogramma (Hymenoptera: Trichogrammatidae) wasps are important biological control agents of lepidopterous insect pests. The genus Trichogramma belongs to the family Trichogrammatidae, which includes 80 genera and approximately 620 species (Pinto and Stouthamer 1994). These parasitic wasps are common natural enemies in agricultural areas surrounding the Mediterranean (Silva et al. 1999; Oztemiz 2007; Pintureau 1987). Thus, Trichogramma species attract significant interest, because of their potential role in biological control. A critical first step for the successful application of Trichogramma in biological control programs is choosing the best species to attack a target pest. Consequently, correct identification of these minute wasps is essential. However, Trichogramma species are difficult to identify because they are both very small and have few distinguishing morphological characters. 
Furthermore, their morphology can be affected by environmental conditions such as host size and temperature (Pinto et al. 1989). Although Nagarkatti and Nagaraja (1971) successfully advocated the use of male genitalia as a character for the identification of Trichogramma, one important limitation of this technique is that females remain unidentifiable (Stouthamer et al. 1999). This is particularly troublesome because field population sex ratios of these wasps are often female biased (Pinto 1999), and all female populations are relatively common in this genus (Huigens and Stouthamer 2003; Vavre et al. 2004).

Since classical morphological methods are not always precise enough to differentiate micro-hymenopteran species to the species level (Landry et al. 1993), genetic means have become the "tools of choice" for the routine identification of Trichogram$m a$ species. Recent studies have focused on the use of the DNA sequence of internal transcribed spacer (ITS2) regions of nuclear rRNA for species identification. Nuclear rRNA consists of three highly conserved regions that code for the ribosomal RNA, separated by two spacer regions that are largely conserved within species, but vary substantially between species. The polymerase chain reaction (PCR) can be used to amplify these ITS spacers, using universal primers that bind in the highly conserved regions. Since these regions are so conserved, the primers work on a wide variety of taxa. Stouthamer et al. (1999) showed the usefulness of the ITS2 sequence as a general identification method for Trichogramma, and the sequence has also aided the description of at least one new Trichogramma species, T. itsybitsi Pinto and Stouthamer, (Pinto et al. 2002). For routine identification, inter-specific variation in ITS2 has been exploited, resulting in the development of several molecular keys for the identification of Trichogramma species occurring in: restricted areas (Silva et al. 1999; Ciociola et al. 2001b; Thomson et al. 2003); particular crops (Pinto et al. 2002); or simply as a method to distinguish closely related species (Borghuis et al. 2004; Chang et al. 2001; Ciociola et al. 2001a; Dang et al. 2005; Sappal et al. 1995; Stouthamer et al. 1999, 2000a, b).

The aim of this study was to develop a general molecular key to the common species known to occur in the agricultural areas of countries bordering the Mediterranean (see Table 1). The key was developed

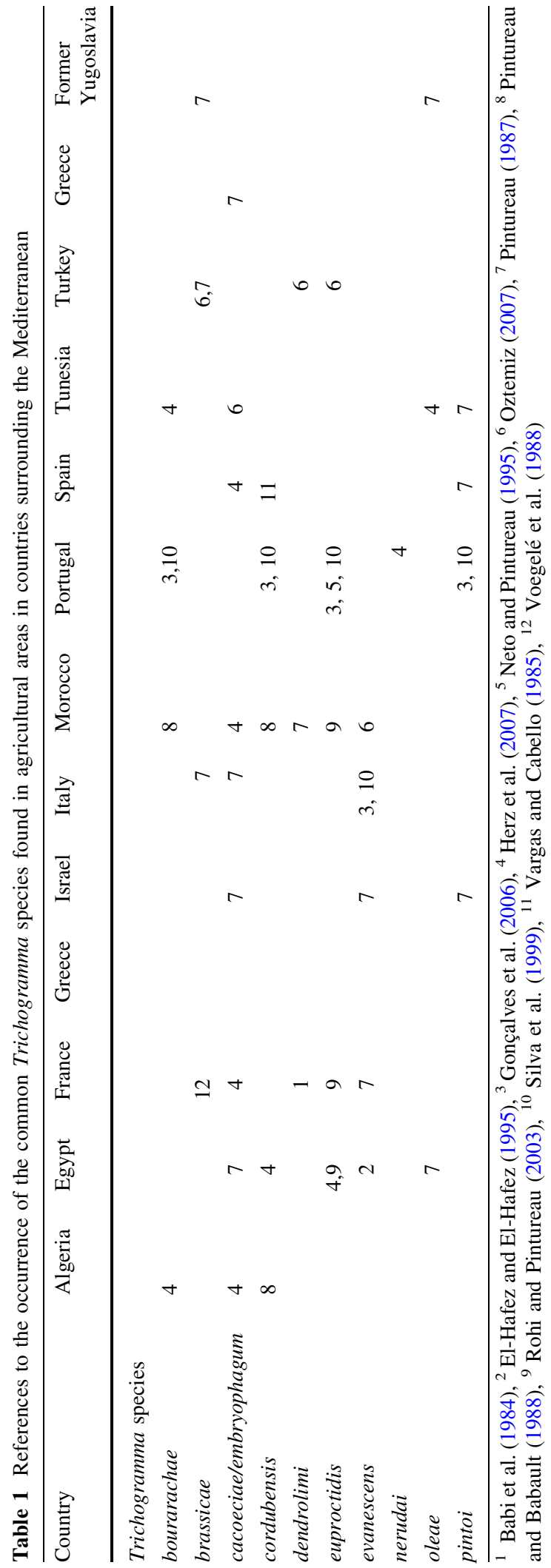


using ITS2 sequences, and species can be distinguished using the size of the ITS2 PCR product alongside the restriction fragment length polymorphism (RFLP) "fingerprint" generated from this amplicon after digestion with particular restriction enzymes.

\section{Materials and methods}

Construction of molecular key for the identification of common Trichogramma found in the Mediterranean region

Eleven species of Trichogramma have been commonly collected in agricultural settings in countries surrounding the Mediterranean: Trichogramma species: T. bourarachae Pintureau and Babault, $T$. brassicae Bezdenko, T. cacoeciae Marchal, T. cordubensis Vargas and Cabello, T. dendrolimi Matsumura, T. embryophagum Hartig, T. euproctidis Girault, T. evanescens Westwood, T. nerudai Pintureau and Gerding, T. oleae Voegelé and Pointel, and T. pintoi Voegelé (Table 1). However, in this study we do not distinguish between T. embryophagum and $T$. cacoeciae since they do not differ in their ITS2 sequence, and the specific relationship between these two species remains ambiguous, although males of these species are distinguishable (Pintureau 2008), albeit that the males of $T$. cacoeciae are exceedingly rare (Stouthamer et al. 1990). For each of the ten species, published ITS2 sequences were retrieved from GenBank (see Table 2 for accession numbers).
These sequences were then used to construct a molecular key to this particular assembly of species, based on the size of the ITS2 spacer and the pattern of RFLPs generated when the ITS2 PCR product is cut using different restriction enzymes. To determine how the different ITS2 sequences are cut by a suite of restriction enzymes (Table 2) we used the restriction map generator as implemented in the program BioEdit (Hall 1999).

For many species only the ITS2 sequences have been deposited in GenBank. However, when a PCR reaction with the ITS2 primers for Trichogramma is done an additional $113 \mathrm{bp}$ are amplified (see Stouthamer et al. 1999). These additional bp are located in the 5.8S rDNA and in the 28S rDNA. These sequences are extremely conserved and do not differ within or between species. To determine the expected restriction patterns from PCR products, we add these sequences to the GenBanks "pure" ITS2 sequence before submitting them to the restriction map generator.

Based on the predicted restriction fragment sizes of the different species, the restriction enzymes MseI, $M n l I$ and $D r a I$ were chosen to produce a simple key to distinguish the ten species (Table 3). Although we are using a single accession number to initially construct the key, other deposited sequences for the same species can also be keyed out using the key. We checked the applicability of the key for all deposited sequences of the species present in GenBank (see Table 4). Finally this key was tested on PCR products obtained from specimens derived from other cultures of each species in the assemblage (see Table 5).

Table 2 Predicted restriction fragment sizes when the different PCR products of the ITS2 are cut by different restriction enzymes

\begin{tabular}{lllll}
\hline & $\begin{array}{l}\text { GenBank } \\
\text { accession } \#\end{array}$ & $\begin{array}{l}\text { Size PCR } \\
\text { product }\end{array}$ & MseI & MnlI \\
\hline T. euproctidis & AF043614 & 489 & 489 & $82,137,270$ \\
T. brassicae & AY182766 & 519 & $32,75,412$ & $82,129,308$ \\
$T$. oleae & U74601 & 512 & 512 & $82,139,140,151$ \\
$T$. dendrolimi & AF453560 & 516 & 74,442 & $56,68,76,82,109,125$ \\
$T$. cordubensis & AF043619 & 529 & 529 & $57,82,94,296$ \\
$T$. evanescens & AF043617 & 548 & 94,454 & $82,169,297$ \\
$T$. cacoeciae & AF408654 & 578 & 204,374 & 578 \\
$T$. pintoi & AY182757 & 694 & $4,15,34,126,170,345$ & $82,120,180,312$ \\
$T$. bourarachae & AF043624 & 666 & 50,616 & $82,125,459$ \\
$T$. nerudai & AY182756 & 745 & $7,8,120,125,485$ & $82,166,497$ \\
\hline
\end{tabular}


Table 3 Molecular key to the common Trichogramma species found in the Mediterranean area based on the ITS2 PCR product and restriction fragments after digestion with the restriction enzymes $M n l I, M s e I$ and $\mathrm{DraI}$

\begin{tabular}{|c|c|c|}
\hline \multirow[t]{2}{*}{1} & PCR product smaller than $500 \mathrm{bp}$ & euproctidis \\
\hline & PCR product larger than $500 \mathrm{bp}$ & 2 \\
\hline \multirow[t]{2}{*}{2} & PCR product smaller than $550 \mathrm{bp}$ & 3 \\
\hline & PCR product larger than $550 \mathrm{bp}$ & 7 \\
\hline \multirow[t]{2}{*}{3} & MseI does not cut PCR product & 4 \\
\hline & MseI cuts PCR product & 5 \\
\hline \multirow[t]{2}{*}{4} & PCR product restricted with $M n l \mathrm{I}$ has a largest band $>270 \mathrm{bp}$ & cordubensis \\
\hline & Largest band $150 \mathrm{bp}$ & oleae \\
\hline \multirow[t]{2}{*}{5} & DraI does not cut PCR product & 6 \\
\hline & DraI cuts PCR product in two parts, the largest band $\sim 400 \mathrm{bp}$ & brassicae \\
\hline \multirow[t]{2}{*}{6} & PCR product restricted with $M n l I$ has a largest band $>300$ bp & evanescens \\
\hline & PCR product restricted with $M n l I$ has a largest band $<170$ bp & dendrolimi \\
\hline \multirow[t]{2}{*}{7} & PCR product $570-590 \mathrm{bp}$ & cacoeciaelembryophagum \\
\hline & PCR product larger than $650 \mathrm{bp}$ & 8 \\
\hline \multirow[t]{2}{*}{8} & PCR product ca $750 \mathrm{bp}$ & nerudai \\
\hline & PCR product smaller than $700 \mathrm{bp}$ & 9 \\
\hline \multirow[t]{2}{*}{9} & PCR product restricted with $M n l \mathrm{I}$ results in several bands with the largest ca $300 \mathrm{bp}$ & pintoi \\
\hline & PCR product restricted with $M n l$ I results in several bands with the largest ca $450 \mathrm{bp}$ & bourarachae \\
\hline
\end{tabular}

Table 4 GenBank accession numbers of the ITS2 sequences of Trichogramma that were used to determine if the molecular key (Table 3) would identify the sequences to the correct species

\begin{tabular}{ll}
\hline $\begin{array}{l}\text { Trichogramma } \\
\text { sp. }\end{array}$ & GenBank accession numbers \\
\hline T. bourarachae & AF043623, AF043625, AF043626, DQ137256, DQ389071, DQ389073, EU882011 \\
T. brassicae & AF453566, AF453567, AY146635, AY146636, AY163002, DQ314611, DQ381280 \\
T. cacoeciae & AF408653, AF453562, AY146642; AY146643, AY146644, AY166700, AY244465, DQ344044, EU547667, \\
& EU547668, EU547669, EU547670, EU547671, EU547672, EU882009, EU882010 \\
T. cordubensis & AF043612, AF043620, DQ137257; DQ137258, DQ389074, U74675 \\
T. dendrolimi & AB094398, AF227949, AF453554, AF453555, AF453556, AF453557, AF453559, AF453561, AF517576, \\
& AY182767, AY244464, AY328907, AY343056, AY343057, AY895013, DQ344045 \\
$\begin{array}{l}\text { T. } \text { euproctidis } \\
\text { T. } \text { evanescens }\end{array}$ & AF043613, AF043615, DQ088061, DQ088062, DQ137263, DQ137264, DQ389076 \\
& AY146639, AY146640, AY146641, AY146645, AY326469, DQ088058, DQ088059; DQ137259, DQ137260, \\
& DQ381280, EU547673, EU547674, EU547675, EU547676, EU547677, EU882008, FJ436332, FJ436333, \\
T. nerudai & AY182756, AY244467, DQ872853 \\
T. oleae & EU547678, EU547679, EU882007 \\
T. pintoi & AF043621, AF043622, DQ088052, DQ137261, DQ137262
\end{tabular}

\section{Trichogramma samples}

Table 5 lists the origin of the specimens used for DNA amplification and RFLP analysis (Figs. 1, 2, 3, 4). DNA was extracted from single wasps using the
Chelex method. In short, wasps were ground in $60 \mu \mathrm{l}$ $5 \%$ Chelex-100 and $2 \mu$ l Proteinase $\mathrm{K}\left(20 \mathrm{mg} \mathrm{ml}^{-1}\right)$, followed by an incubation for $1 \mathrm{~h}$ at $55^{\circ} \mathrm{C}$, and finally by $10 \mathrm{~min}$ at $99^{\circ} \mathrm{C}$. The ITS 2 spacer was then amplified using PCR primers and conditions given in 
Table 5 Collections of Trichogramma species used for PCR amplification and restriction digestion as illustrated in Figs. 1, 2, 3 and 4

\begin{tabular}{lllc}
\hline Species & Strain designation & Origin & Date collected \\
\hline T. euproctidis & PB (Pintureau) & Portugal & 1991 \\
T. brassicae & Bra 2 (Pintureau) & Moldavia & 1973 \\
T. oleae & S2 (Pintureau) & Yugoslavia & 1972 \\
T. dendrolimi & It18 (Pintureau) & Italy & 1991 \\
T. cordubensis & MB35 (Silva) & Portugal & 1994 \\
T. evanescens & A1 (Pintureau) & France & 1989 \\
$T$. cacoeciae & 082090-1(Pinto) & USA & 1990 \\
T. nr. pintoi & $92-25-4$ (Pinto) & Russia & $1992^{\mathrm{a}}$ \\
T. bourarachae & TP-41-E.G (Pintureau) & Egypt & 2002 \\
T. nerudai & TR (Pintureau) & Chili & 1994 \\
\hline
\end{tabular}

${ }^{a}$ Date that the culture was received at UC Riverside

Stouthamer et al. (1999). The size of PCR product was determined by electrophoresis on a $1 \%$ agarose gel stained with ethidium bromide. Restriction digestion of the PCR products were performed in $15 \mu \mathrm{l}$ reactions containing $10 \mu \mathrm{l}$ PCR product, $1 \times$ the appropriate buffer, and 10 units of the restriction enzyme MseI, DraI or MnlI (New England BioLabs, Ipswich, MA, USA). MseI and MnlI reactions also contained $100 \mu \mathrm{g} \mathrm{ml}^{-1}$ BSA (NEB). Digests were incubated at $37^{\circ} \mathrm{C}$ for $2 \mathrm{~h}$ and then inactivated at $65^{\circ} \mathrm{C}$ for $20 \mathrm{~min}$. Restriction products were visualized after electrophoresis on $2 \%$ agarose gels stained with ethidium bromide.

\section{Results}

In this assemblage of species, T. euproctidis is distinguished from all others by the small size of its ITS2 spacer (<500 bp; Tables 2, 3; Fig. 1). The remaining species can be separated into two groups based on the size of the ITS2 PCR product (Tables 2, 3; Fig. 1). Species with an ITS2 PCR product between 500 and $550 \mathrm{bp}$ consist of $T$. brassicae, T. oleae, T. cordubensis, T. evanescens and $T$. dendrolimi. These species can subsequently be distinguished using the restriction enzymes MseI, MnlI and DraI (see Figs. 2, 3, 4; Table 3). Species with an ITS2 product larger than $550 \mathrm{bp}$ can be distinguished based on the size of the PCR product with T. cacoeciaelembryophagum at around 570$590 \mathrm{bp}$, T. nerudai at around $750 \mathrm{bp}$ (see Fig. 1), and finally $T$. pintoi and $T$. bourarachae at around 660-695 bp. The latter pair can subsequently be distinguished using the restriction enzyme $M n l \mathrm{I}$ (Fig. 4; Table 3). We also tested the key on the sequences deposited in GenBank for the species used in this key (See Table 4), to make sure that the restriction patterns we had chosen would apply to all the known sequences for these species, and indeed the different species can be identified unambiguously using the GenBank sequences.

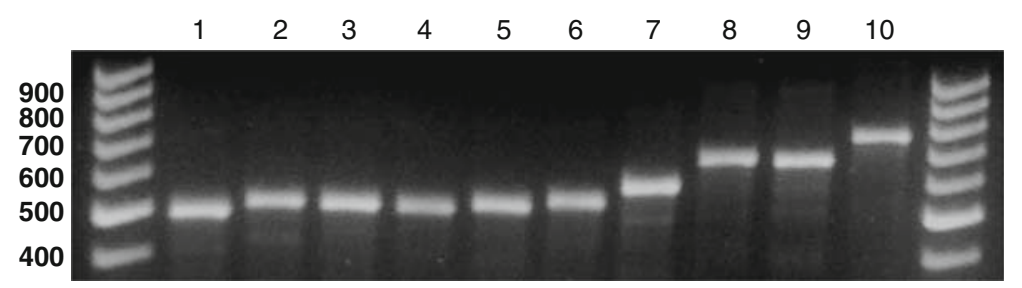

Fig. 1 Undigested ITS2 product, consisting of the ITS2 plus amplified parts of the 5.8 and 28S rDNA. Outer lanes contain size standards (GeneRuler ${ }^{\text {TM }} 100$ bp DNA Ladder, Fermentas Life Sciences, Glen Burnie, Maryland, USA). Lane 1-10 the amplified products, with 1: T. euproctidis, 2: T. brassicae, 3: T. oleae, 4: T. dendrolimi, 5: T. cordubensis, 6: T. evanescens, 7: T. cacoeciae, 8: T. pintoi, 9: T. bourarachae and 10: T. nerudai 


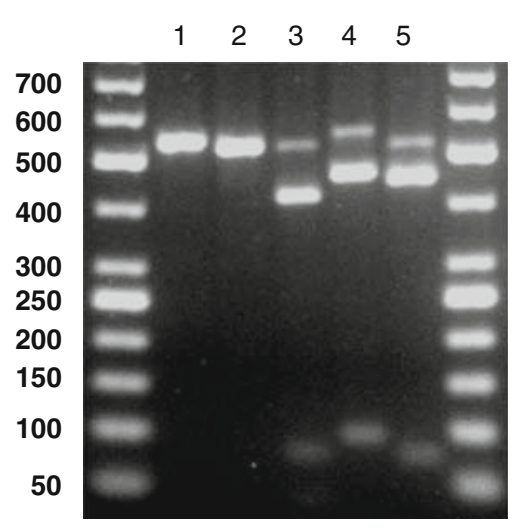

Fig. 2 MseI digestion of PCR products consisting of the ITS2 plus flanking regions of the 5.8 and 28S rDNA Outer lanes contain size standards (GeneRuler ${ }^{\mathrm{TM}} 50$ bp DNA Ladder, Fermentas Life Sciences). Lane 1-5 the digested products, with 1: T. cordubensis, 2: T. oleae, 3: T. brassicae, 4. T. evanescens and 5: T. dendrolimi

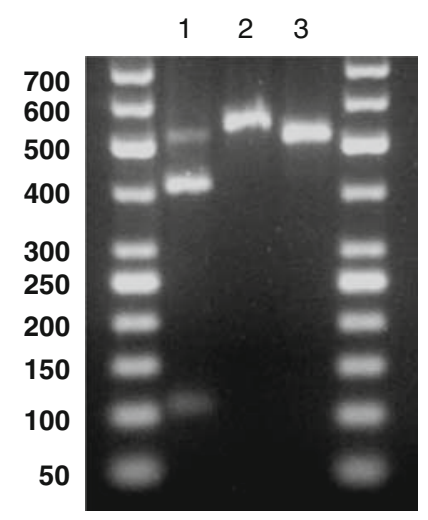

Fig. 3 DraI digestion of PCR products consisting of the ITS2 plus flanking regions of the 5.8 and $28 \mathrm{~S}$ rDNA Outer lanes contain size standards (GeneRuler ${ }^{\mathrm{TM}} 50 \mathrm{bp}$ DNA Ladder, Fermentas Life Sciences). Lane 1-3 the digested products, with 1: T. brassicae, 2: T. evanescens, 3: T. dendrolimi

\section{Discussion}

The molecular key given here provides a simple tool to help students of Trichogramma to precisely and rapidly identify the most common species found in the agricultural areas around the Mediterranean. The key was developed by using ITS2 DNA sequences deposited in GenBank, for each species initially a single sequence was chosen to represent that species. During the construction of the key several other sequences of the same species were checked to make sure that the RFLP pattern used in the key indeed was present in other sequenced specimen as well. Upon

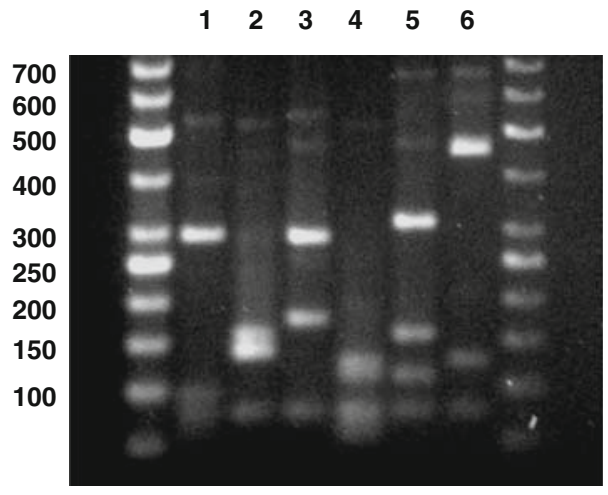

Fig. $4 M n l$ digestion of PCR products consisting of the ITS2 plus flanking regions of the 5.8 and 28S rDNA Outer lanes contain size standards (GeneRuler ${ }^{\mathrm{TM}} 50$ bp DNA Ladder, Fermentas Life Sciences). Lane 1-6 the digested products, with 1: T. cordubensis, 2: T. oleae, 3: T. evanescens, 4. T. dendrolimi. 5. T. pintoi and 6: T. bourarachae

completion of the key we tested the working of the key against all correctly deposited ITS 2 sequences in GenBank. Some of the ITS2 sequences in GenBank are associated with the wrong species name. For instance two sequences under accession numbers AF453568 and AF453569 are listed as T. maidis (= brassicae) but are sequences of $T$. evanescens. These accessions were placed in the file with the correct species to determine if the species would be keyed out correctly. In addition we tested our key against a set of morphologically identified specimens obtained from the collections of the Trichogramma systematists Pintureau (Villeurbanne, France) and John Pinto (Riverside, California, USA).

The association of the wrong species name with a sequence reflects the problem that has haunted Trichogramma research for a long time. Names associated with cultures often do not reflect the correct species. In the past species could only be reliably identified by a few specialists in Trichogramma morphology, but not all initial identifications were done by such specialists. Secondly even if cultures were initially identified correctly, contamination in the laboratory may have taken place. Many students of Trichogramma maintain collections consisting of several species.

As with all keys, if only a subset of the species included in this key are known to be present in a particular area, their identification can be further simplified and certain restriction digests can be avoided. An example of this may be the difference 
between $T$. bourarachae and T. pintoi. As far as we are aware, this latter species has only been found commonly in tomato crops in Portugal. Similarly, $T$. nerudai may be limited to Portugal, since the natural distribution of T. nerudai is South America, and its presence in Portugal is unusual since no known releases of this species have taken place (Herz et al. 2007). Also in Portugal the species T. brassicae has not been found in tomato fields. And a much simpler key for those particular circumstance can be found in Silva et al. (1999). If the Trichogramma fauna of a particular crop or region is well known another approach to streamlining their identification would be the development of a species-specific multiplex PCR. In such a multiplex PCR, for each species a specific primer is designed, so that when combined in a single reaction with a complementary universal primer, all the species can be identified by the size of the resulting PCR product alone (Gariepy et al. 2005; Davies et al. 2006). Development of such multiplex primers is very feasible but the choice of primers depends on the species that are present.

As with all keys, one limitation of our method is that if species not included in the key are encountered, they cannot be identified unless characters such as the size of their ITS2 spacer and/or its RFLP pattern deviate from those of the included species. This could potentially result in "false" identifications and if such circumstances are suspected, the ITS2 spacer of the species would need to be sequenced in order to identify that species.

Finally, in addition to the use of our key for identifying field collected wasps, we suggest that this method may also be used for quality control purposes. Mass rearings of Trichogramma are particularly prone to contamination by other species. Contamination with different species is difficult to avoid, indeed in our own collection of Trichogramma cultures we always test the species identity of our cultures before we do experiments and more often than once we find that the culture has been contaminated by another species. Similarly we have tested the identity of collections of species used by other Trichogramma researchers and have often found that the Trichogramma name applied to the specimen of a particular collection are incorrect. Sometime this is caused by the changing insights in the species name of taxa, such as for instance T. maidis that is now called $T$. brassicae or $T$. turkestanica now called
T. euproctidis. In other cases the name and the true species identity are not the same. In case of biological control applications this can lead to release of the wrong species and a failure of biological control. One particularly difficult case to notice is $T$. minutum and T. platneri, these two species are morphologically identical (Pinto et al. 2003) and even do not differ in their ITS2 sequence (Stouthamer et al. 2000a), specimens can only be distinguished by the sequence of their COII gene (Borghuis et al. 2004). The release of the wrong species in an area where the other is native can lead to a prolonged suppression of the population of both native and introduced species in biological control applications (Stouthamer et al. 2000b). The species sold through North American biocontrol producers in this complex are sometimes not identified correctly (Stouthamer unpublished). We have also found similar problems in the mid 1990s in Trichogramma sold in Europe for the control of the European Corn Borer (Ostrinea nubilalis). Using techniques similar to those given here it should be relatively simple to check on the correct species identification of wasps used in biological control. Students of Trichogramma and biological control workers alike should make sure that the species they report on working or releasing is indeed the correct species.

Acknowledgments Part of the work of F.S. was supported by a grant from The Foundation of Erciyes University.

Open Access This article is distributed under the terms of the Creative Commons Attribution Noncommercial License which permits any noncommercial use, distribution, and reproduction in any medium, provided the original author(s) and source are credited.

\section{References}

Babi A, Pintureau B, Voegelé J (1984) Etude de Trichogramma dendrolimi (Hym.: Trichogrammatidae), description d'une nouvelle sous-espèce. Entomophaga 29:369-379

Borghuis A, Pinto JD, Platner GR, Stouthamer R (2004) Partial cytochrome oxidase II sequences distinguish the sibling species Trichogramma minutum Riley and Trichogramma platneri Nagarkatti. Biol Control 30:90-94

Chang SC, Hu NT, Hsin CY, Sun CN (2001) Characterization of differences between Two Trichogramma wasps by molecular markers. Biol Control 21:75-78

Ciociola AI Jr, Querıno RB, Zucchı RA, Stouthamer R (2001a) Molecular tool for identification of closely related species 
of Trichogramma: T. rojasi Nagaraja and T. lasallei Pinto. Neotrop Entomol 30:575-578

Ciociola AI Jr, Zucchi RA, Stouthamer R (2001b) Molecular key to seven Brazilian species of Trichogramma using sequences of the ITS2 region and restriction analysis. Neotrop Entomol 30:259-262

Dang XL, Wen SY, He XF, Pang XF (2005) M-PCR: a powerful method for rapid molecular identification of Trichogramma wasps. Insect Sc 12:77-85

Davies AP, Lange CL, O'Neill SL (2006) A rapid single-step multiplex method for discriminating between Trichogramma species in Australia. J Econ Entomol 99:21422145

El-Hafez AA, El-Hafez ABD (1995) A comparison of thermal requirements and some biological aspects of Trichogramma evanescens Westwood and Trichogrammatoidea bactrae Nagaraja reared from eggs of the pink and spiny bollworms. Ann Agric Sc 40:901-912

Gariepy TD, Kuhlmann U, Haye T, Gilliot C, Erlandson M (2005) A single-step multiplex PCR assay for the detection of European Peristenus spp., parasitoids of Lygus spp. Biocontrol Sc Techn 15:481-495

Gonçalves CI, Huigens ME, Verbaarschot P, Duarte S, Mexia A, Tavares J (2006) Natural occurrence of Wolbachiainfected and uninfected Trichogramma species in tomato fields in Portugal. Biol Control 37:375-381

Hall TA (1999) BioEdit: a user-friendly biological sequence alignment [ed.], and analysis program for Windows 95/98/ NT. Nucleic Acids Symp Ser 41:95-98

Herz A, Hassan SA, Hegazi E, Khafagi WE, Nasr FN, Youssef AI, Agamy E, Blibech I, Ksentini I, Ksantini M, Jardak T, Bento A, Pereira JA, Torres L, Souliotis C, Moschos T, Milonas P (2007) Egg parasitoids of the genus Trichogramma in olive groves of the Mediterranean region. Biol Control 40:48-56

Huigens ME, Stouthamer R (2003) Parthenogenesis associated with Wolbachia. In: Bourtzis K, Miller TA (eds) Insect symbiosis. CRC Press, Boca Raton, pp 247-266

Landry BS, Dextraze L, Boivin G (1993) Random amplified polymorphic DNA markers for DNA fingerprinting and genetic variability assessment of minute parasitic wasp species (Hymenoptera: Mymaridae and Trichogrammatidae) used in biological control programs of phytophagous insects. Genome 36:580-587

Nagarkatti S, Nagaraja H (1971) Redescriptions of some known species of Trichogramma showing the importance of the male genitalia as a diagnostic character. Bull Entomol Res 61:13-31

Neto L, Pintureau B (1995) Taxonomic study of a population of Trichogramma turkestanica discovered in Southern Portugal. Ann Soc Entomol France 31:21-30

Oztemiz S (2007) Trichogramma species egg parasitoids of Lepidoptera in the eastern Mediterranean region of Turkey. Proc Entomol Soc Washington 109:718-720

Pinto JD (1999) The systematics of the North American species of Trichogramma. Memoirs Entomol Soc Wash 22 (1998), p 287

Pinto JD, Stouthamer R (1994) Systematics of the Trichogrammatidae with emphasis on Trichogramma. In: Wajnberg E, Hassan SA (eds) Trichogramma and other egg parasitoids. CAB Intl., London, pp 1-36
Pinto JD, Velten RK, Platner GR, Oatman ER (1989) Phenotypic plasticity and taxonomic characters in Trichogramma. Ann Entomol Soc Amer 83:414-425

Pinto JD, Koopmanschap AB, Platner GR, Stouthamer R (2002) The North American Trichogramma parasitizing certain Tortricidae (Lepidoptera) on apple and pear with ITS2 DNA characterization and description of a new species. Biol Control 23:134-142

Pinto JD, Platner GR, Stouthamer R (2003) The systematics of the Trichogramma minutum species complex (Hymenoptera: Trichogrammatidae), a group of important North American biological control agents: the evidence from reproductive compatibility and allozymes. Biol Control 27:167-180

Pintureau B (1987) Systématique évolutive du genre trichogramma Westwood (Hym. Trichogrammatidae) en Europe. Thèse d'Etat, Université Paris VII, p 311

Pintureau B (2008) Les espèces européennes de trichogrammes. InLibroVeritas, Cergy-Pontoise, p 96

Pintureau B, Babault M (1988) Systématique des espèces africaines des genres Trichogramma Westwood et Trichogrammatoidea Girault. Les Colloques de l'INRA 43:97-120

Rohi L, Pintureau B (2003) Reassessment of Trichogramma euproctidis. Russian Entomol J 12:373-379

Sappal NP, Jeng RS, Hubbes M, Liu F (1995) Restriction fragment length polymorphisms in polymerase chain reaction amplified ribosomal DNAs of three Trichogramma species. Genome 38:419-425

Silva IMMS, Honda J, Van Kan FJPM, Hu J, Neto L, Pintureau B, Stouthamer R (1999) Molecular differentiation of five Trichogramma species occurring in Portugal. Biol Control 16:177-184

Stouthamer R, Pinto JD, Platner GR, Luck RF (1990) Taxonomic status of thelytokous forms of Trichogramma. Ann Entomol Soc Am 83:475-481

Stouthamer R, Hu J, Van Kan FJPM, Platner GR, Pinto JD (1999) The utility of internally transcribed spacer 2 DNA sequences of the nuclear ribosomal gene for distinguishing sibling species of Trichogramma. BioControl 43:421-440

Stouthamer R, Gai Y, Koopmanschap AB, Pinto JD, Platner GR (2000a) ITS-2 sequences do not differ for the closely related species Trichogramma minutum and T. platneri. Entomol Exper et Appl 95:105-111

Stouthamer R, Jochemsen P, Platner GR, Pinto JD (2000b) Crossing incompatibility between Trichogramma minutum and T. platneri (Hymenoptera: Trichogrammatidae): implications for application in biological control. Environ Entomol 29:832-837

Thomson L, Rundle BJ, Carew ME, Hoffmann AA (2003) Identification and characterization of Trichogramma species from south-eastern using the internal transcribed spacer 2 (ITS2) region of the ribosomal gene complex Entomol. Exper et Appl 106:235-240

Vargas P, Cabello T (1985) A new species of Trichogramma (T. cordubensis n. sp.), parasitoid of Heliothis eggs in cotton crops in the SW of Spain. Entomophaga 30:225-230

Vavre F, de Jong JH, Stouthamer R (2004) Cytogenetic mechanism and genetic consequences of thelytoky in the wasp Trichogramma cacoeciae. Heredity 93:592-596

Voegelé J, Pizzol J, Babi A (1988) The overwintering of some Trichogramma species. Colloques de l'INRA 43:275-282 